\title{
Organo-montimorillonites containing a reactive thiophene group for polythiophenes nanocomposites
}

\section{(Montmorilonitas organofilizadas contendo grupos tiofeno reativos para preparação de nanocompósitos de politiofenos)}

\author{
J. C. Macêdo-Fonsêcal ${ }^{*}$, A. A. A. Tino ${ }^{2}$, M. P. A. Silva-Alves ${ }^{2}$, R. M. Souto-Maior ${ }^{2}$ \\ ${ }^{I}$ Unidade Acadêmica do Cabo de Santo Agostinho, Universidade Federal Rural de Pernambuco, Condomínio \\ Logístico Cone Suape Multimodal, BR 101 Sul, $n^{\circ}$ 5225, Ponte dos Carvalhos, Cabo de Santo Agostinho, PE \\ ${ }^{2}$ Departamento de Química Fundamental, Universidade Federal de Pernambuco, Av. Jornalista Anibal \\ Fernandes, $s / n^{\circ}$, Recife, PE, Brazil 50740-560 \\ *juliana.macedo@uacsa.ufrpe.br
}

\begin{abstract}
A sodium montmorillonite clay $\left(\mathrm{Na}^{+} \mathrm{MMT}\right)$ was modified with different contents of a reactive salt derived from thiophene (trimethyl-(2-thiophen-3-yl-ethyl)-ammonium bromide) (TMETA). The thiophene salt in the organoclay (xtioMMT) was oxidatively polymerized in situ, giving rise to montmorillonite clay intercalated with a polythiophene salt (xpoltioMMT). Analysis by Fourier transform infrared spectroscopy shows a difference in organization of the salt inside the clay lamellae, before and after its polymerization. X-ray diffraction indicates that the salts, whether polymeric or not, are arranged as a monolayer for all compositions. Differently to the expected, the thermal stability of the organoclays decreases upon polymerization suggesting degradation of TMETA in the polymerization reaction.
\end{abstract}

Keywords: montmorillonite, thiophene, quaternary ammonium salt, organoclay.

\section{Resumo}

Uma argila montmorilonita sódica (Na $\mathrm{MMT}^{+}$foi modificada com diferentes teores de um sal quaternário de amônio reativo, derivado de tiofeno, brometo de (3-tienil)-2-etiltrimetilamônio (TMETA). O sal de tiofeno intercalado na argila foi polimerizado in situ por via oxidativa, originando uma argila montmorilonita intercalada com um sal de politiofeno (xpoltioMMT). A análise de espectroscopia de infravermelho com transformada de Fourier mostra a diferença entre as maneiras de organização do sal no espaçamento interlamelar das argilas, antes e após a polimerização do sal. A análise de difração de raios $X$ indicou que independente do sal se encontrar na forma polimérica ou monomérica, este se arranja na forma de monocamada para todas as composições de sal intercalado. Diferente do esperado, a estabilidade térmica da argila organofilica diminui após a polimerização do sal orgânico intercalado, sugerindo que ocorreu degradação do TMETA durante a reação de polimerização.

Palavras-chave: montmorilonita, sais quaternários de amônio, argila organofílica.

\section{INTRODUCTION}

The preparation of polymer-clay nanocomposites represents an important application of montmorillonite (MMT) clays. Among the methods adopted to make compatible the hydrophilic clay with the polymer, generally hydrophobic, the incorporation of ammonium salts or quaternary ammonium salts having long alkyl chains in the interlayer spacing of the clay prevails [1]. More recently, oligomeric and polymeric compatibilizing agents have also been used [2,3]. Clays modified by polymeric salts present improved thermal stability and makes it possible the preparation of nanocomposites of polymers, which due to their nonpolarity are incompatible even with the clays modified by long alkyl chains ammonium surfactant salts. For example, nanocomposites of polypropylene (PP) and polyethylene (PE), presenting both intercalated and exfoliated structures, have been obtained with clays modified by polymeric surfactants $[4,5]$. Nanocomposites of $\pi$-conjugated polymers and MMT have also been studied [6-8]. Among them are those of polythiophenes, a family of conductive polymers presenting functional groups which make them candidates for diverse applications such as microelectronic devices [9], catalysts [10], chemical and biosensors [11, 12], among others.

Studies focusing on nanocomposites of poly (3-alkylthiophenes) with MMT were published recently, showing that these materials have improved electrical conductivity and photoluminescence [13-16]. The reported nanocomposites were made with both sodium-MMTs and organo-MMTs intercalated with non-polymeric surfactants. The sodium-MMT nanocomposite was obtained through in situ polymerization in solution and had intercalated structure 
[17], while the nanocomposites made with organoclays presented structures containing mainly intercalated domains when prepared by the melt-cooled and solvent cast method $[13,14,17]$. A polythiophene having ammonium moieties in its lateral alkyl chains was used in the construction of organicinorganic superlattices [18], and ammonium quaternary salts derived from thiophene were used as both monomers and induction agents for the formation of mesoporous structures in polythiophenes-silica composites which presented intense fluorescence [19]. In this paper the results of the preparation and characterization of MMT clays modified by a quaternary ammonium salt containing a thiophene moiety trimethyl(2-thiophen-3-yl-ethyl)-ammonium bromide (TMETA) and MMT clays modified by a polythiophene obtained by in situ polymerization of the salt were present. The objective of this work was the preparation and characterization of organoclays with increased potential of exfoliation for the preparation of polythiophenes nanocomposites.

\section{EXPERIMENTAL}

Materials: a cloisite ${ }^{\circledR} \mathrm{Na}^{+}$montmorillonite $\left(\mathrm{Na}^{+} \mathrm{MMT}\right)$ with cation exchange capacity (CEC) of $90 \mathrm{meq} / 100 \mathrm{~g}$ from Southern Clay Products was used. Trimethylamine solution (31-35\% in ethanol, approximately $4.2 \mathrm{M}$ ), 3-thiopheneethanol (99\%), and phosphorous bromide (1.0 M solution in dichloromethane) from Sigma-Aldrich were used as received.

Synthesis of TMETA: the ammonium salt of thiophene was synthesized in two steps (Fig. 1) based on literature procedures $[20,21]$, as described below.

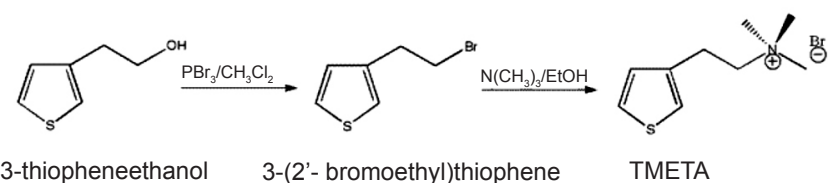

Figure 1: Synthetic route to trimethyl-(2-thiophen-3-yl-ethyl)ammonium bromide.

[Figura 1: Rota sintética do brometo de(3-tienil)-2-etiltrimetilamônio.]

3-(2'-bromoethyl) thiophene: a solution of $\mathrm{PBr}_{3}$ in $\mathrm{CH}_{2} \mathrm{Cl}_{2}(13 \mathrm{~mL}, 13 \mathrm{mmol})$ was added dropwise to 3-thiopheneethanol $(5.0 \mathrm{~g}, 39 \mathrm{mmol})$, dissolved in $5 \mathrm{~mL}$ of anhydrous methylene chloride, at $0{ }^{\circ} \mathrm{C}$ and under $\mathrm{N}_{2}$ atmosphere. The mixture was stirred for $48 \mathrm{~h}$ at room temperature and the reaction was terminated by the addition of $50 \mathrm{~mL}$ of a saturated aqueous sodium chloride solution. The organic layer was separated, treated with $10 \%$ aqueous $\mathrm{NaHCO}_{3}$, followed by $10 \%$ aqueous $\mathrm{NaHSO}_{3}$. The organic solution was dried over anhydrous magnesium sulfate. After filtration the solvent was removed by rotary evaporation leaving a slightly yellow oil. Vacuum distillation of this oil gave $4.01 \mathrm{~g} \mathrm{(59 \% )}$ of 3-(2'-bromoethyl) thiophene. MS $(\mathrm{ESI}): \mathrm{t}_{\mathrm{r}}=8.2 \mathrm{~min} ; \mathrm{m} / \mathrm{z}(\%)=190,194(50)\left[\mathrm{M}^{+}\right] ; 111(65)$; 97 (100); 77 (28); 67 (20); 45 (85). ( $\left.\mathrm{C}_{6} \mathrm{H}_{7} \mathrm{SBr}\right) . \mathrm{H}^{1} \mathrm{NMR}(300$
$\left.\mathrm{MHz}, \mathrm{CDCl}_{3}\right): \delta 7.3\left(\mathrm{dd}, J_{5,4},=4.9 \mathrm{~Hz}\right.$ and $J_{5,2},=3.0 \mathrm{~Hz}, 1 \mathrm{H}$ ); $\delta 7.1(\mathrm{~d}, J=2.1 \mathrm{~Hz}, 1 \mathrm{H}) ; \delta 7.0\left(\mathrm{~d}, J_{2,5},=4.9 \mathrm{~Hz}, 1 \mathrm{H}\right) ; \delta 3.6(\mathrm{t}$, $\mathrm{J}=7.5 \mathrm{~Hz}, 2 \mathrm{H}) ; \delta 3.24(\mathrm{t}, J=7.5 \mathrm{~Hz}, 3 \mathrm{H})$.

TMETA: to 3-(2-bromoethyl) thiophene $(5.9 \mathrm{~g}, 30.8$ mmol) under $\mathrm{N}_{2}$ atmosphere, $10 \mathrm{~mL}$ of a $4.0 \mathrm{M}$ solution of trimethylamine in ethanol was added. The reaction mixture was refluxed and stirred for $10 \mathrm{~h}$. The solvent was then removed by rotary evaporation yielding a white solid, which was purified by recrystallization from isopropanol; yield $5.19 \mathrm{~g}$ (98\%). FT-IR (KBr): 3070, 3045, 3004, 2926, 2860, 1542, 1486, 1034, 978, 766, $624 \mathrm{~cm}^{-1} .{ }^{1} \mathrm{H}$ RMN (300 $\left.\mathrm{MHz}, \mathrm{D}_{2} \mathrm{O} ; \delta\right): 7,4\left(\mathrm{dd}, \mathrm{J}_{5^{\prime}, 4}=5 \mathrm{~Hz}\right.$ and $\left.\mathrm{J}_{5^{\prime}, 2}=3 \mathrm{~Hz}, 1 \mathrm{H}\right) ; \delta$ $7.2(\mathrm{~s}, 1 \mathrm{H}) ; \delta 7.0\left(\mathrm{~d}, \mathrm{~J}_{2,5},=5 \mathrm{~Hz}, 1 \mathrm{H}\right) ; \delta 3.5-3.4(\mathrm{~m}, 2 \mathrm{H}) ; \delta$ $3.07(\mathrm{~m}, 2 \mathrm{H}) ; \delta 3.1(\mathrm{~s}, 9 \mathrm{H}) .{ }^{13} \mathrm{C} \mathrm{RMN}\left(300 \mathrm{MHz}, \mathrm{D}_{2} \mathrm{O} ; \delta\right): \delta$ $23.5\left(\mathrm{CH}_{2}\right) ; \delta 53.0\left(\mathrm{CH}_{3}\right) ; \delta 53.04\left(\mathrm{CH}_{3}\right) ; \delta 53,08\left(\mathrm{CH}_{3}\right) ; \delta$ $66.2\left(\mathrm{CH}_{2}\right) ; \delta 122.8 ; 126.9 ; 128.0 ; 135.6$.

Preparation of montmorillonites intercalated with TMETA: MMT modified by TMETA was prepared according to [22]. The organoclays were named xtioMMT where $\mathrm{x}$ is the amount of salt loaded which was $0.5,1.0$ and 1.5 CEC equivalents. $\mathrm{Na}^{+} \mathrm{MMT}(1 \mathrm{~g})$ was stirred in $90 \mathrm{~mL}$ distilled water for circa $24 \mathrm{~h}$ at room temperature $\left(26{ }^{\circ} \mathrm{C}\right)$ until a homogenous suspension was formed. The appropriate amount of TMETA, dissolved in $10 \mathrm{~mL}$ of distillated water was added to the Na-MMT suspension. The mixture was stirred at $70{ }^{\circ} \mathrm{C}$ for $3 \mathrm{~h}$ and then allowed to stand for $24 \mathrm{~h}$. The slurry was centrifuged and the supernatant discarded. The organoclay was repeatedly washed with distilled water and centrifuged, until a clear supernatant was obtained. The organoclay was oven dried at $60^{\circ} \mathrm{C}$ and powdered.

Polymerization of TMETA in the interlayer spacement of $M M T$ : the organoclay (xtioMMT) $(1 \mathrm{~g})$ and anhydrous ferric chloride $(4: 1 \mathrm{~mol} / \mathrm{mol}$ in relation to the nominal salt content in the clay) dispersed in $50 \mathrm{~mL}$ of dry chloroform were stirred at room temperature $\left(26^{\circ} \mathrm{C}\right)$, under $\mathrm{N}_{2}$ atmosphere. After $40 \mathrm{~h}$ of stirring, the slurry was centrifuged and the supernatant discarded. The precipitate was repeatedly washed with methanol until the supernatant was clear. The clay (xpoltioMMT) was oven dried at $60^{\circ} \mathrm{C}$ and powdered.

Fourier transform infrared (FTIR) spectroscopy: FTIR spectra were recorded on a Bruker ISF66 instrument. Pressed pellets of the samples in $\mathrm{KBr}$ were used.

$X$-ray diffraction $(X R D)$ : data were collected with a Siemens Diffract ACT 1000 diffractometer, using $\mathrm{Cu}-\mathrm{K} \alpha$ radiation $(\lambda=0.154 \mathrm{~nm})$, from $2 \theta=1.5^{\circ}$ to $30^{\circ}$ and a step size of $0.02 \% \mathrm{~min}$. The basal spacing values $\left(\mathrm{d}_{001}\right)$ were calculated by Bragg's law: $\mathrm{d}_{001}=\lambda /(2 \sin \theta)$.

Thermogravimetric analysis (TG): was carried out on a Netzch STA 449F3-Jupiter analyzer under a flowing $\mathrm{N}_{2}$ atmosphere $(20 \mathrm{~mL} / \mathrm{min})$ at a scan rate of $10{ }^{\circ} \mathrm{C} / \mathrm{min}$ from 40 to $800{ }^{\circ} \mathrm{C}$.

\section{RESULTS AND DISCUSSION}

\section{FTIR spectroscopy}

Fig. 2 shows the FTIR spectra of TMETA, $\mathrm{Na}^{+} \mathrm{MMT}$, 
50tioMMT, 100tioMMT and 150tioMMT. The spectrum of TMETA(Fig. 2a) shows bands at 3070 and $3045 \mathrm{~cm}^{-1}$ attributed to the aromatic $\mathrm{C}_{\beta}-\mathrm{H}$ and $\mathrm{C}_{\alpha}-\mathrm{H}$ stretchings respectively, and at 3004 and $2946 \mathrm{~cm}^{-1}$ due to the $v_{\text {asym }} \mathrm{H}_{3} \mathrm{C}-\mathrm{N}^{+}$and $v_{\text {sym }} \mathrm{H}_{3} \mathrm{C}-\mathrm{N}^{+}$, respectively [23, 24]. The bands at 2926 and $2860 \mathrm{~cm}^{-1}$ correspond to the $v_{\text {asym }} \mathrm{C}-\mathrm{H}$ and $\mathrm{v}_{\mathrm{sym}} \mathrm{C}-\mathrm{H}$ respectively, in methylene groups. The characteristic aromatic ring $v_{\text {asym }} \mathrm{C}=\mathrm{C}$ appears at $1542 \mathrm{~cm}^{-1}$ [25], and a strong band at $1486 \mathrm{~cm}^{-1}$ is due to the asymmetric $\mathrm{C}-\mathrm{H}$ bending vibrations in the $\mathrm{CH}_{3}$ groups [26]. The spectrum of $\mathrm{Na}^{+} \mathrm{MMT}$ (Fig. 2b) shows an $\mathrm{O}-\mathrm{H}$ stretching band at $3636 \mathrm{~cm}^{-1}$ due to structural hydroxyl

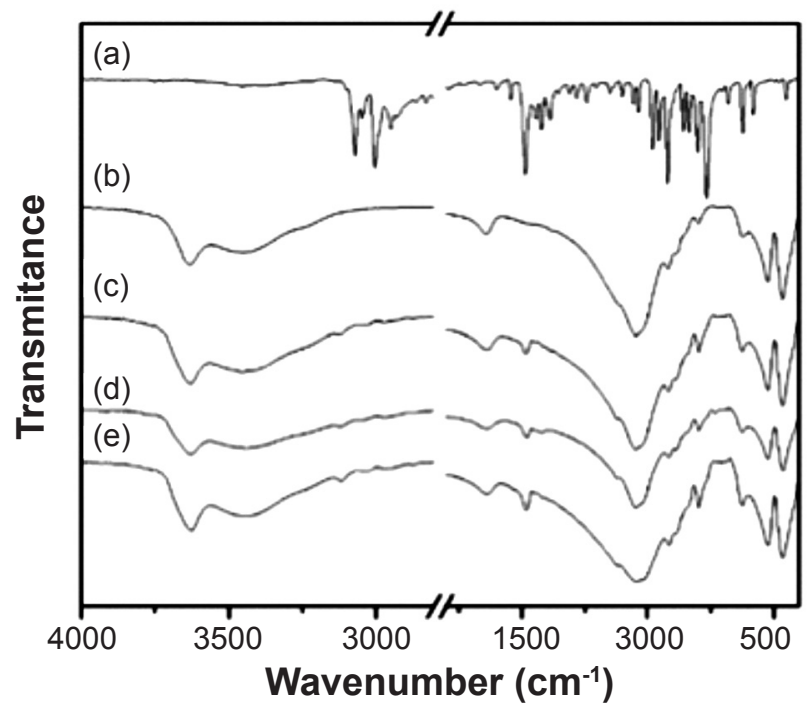

Figure 2: FTIR spectra of (a) TMETA, (b) $\mathrm{Na}^{+} \mathrm{MMT}$, (c) 50tioMMT, (d) 100tioMMT and (e) 150tioMMT.

[Figura 2: Espectros de infravermelho com transformada de Fourier (FTIR) do (a) TMETA, (b) $\mathrm{Na}^{+} \mathrm{MMT}$, (c) 50tioMMT, (d) 100tioMMT e (e) 150tioMMT.] groups and a broad $\mathrm{H}-\mathrm{O}-\mathrm{H}$ stretching band at approximately $3450 \mathrm{~cm}^{-1}$ due to adsorbed water [27], a strong broad band at $1045 \mathrm{~cm}^{-1}$ due to Si-O stretching vibrations and bands at 526 and $467 \mathrm{~cm}^{-1}$ attributed to Si-O-Al and Si-O-Si bending vibrations, respectively [28]. In the spectra of 50tioMMT (Fig. 2c), 100tioMMT (Fig. 2d) and 150tioMMT (Fig. 2e) bands of TMETA can be seen in the $3200-2800 \mathrm{~cm}^{-1}$ region and at $1480 \mathrm{~cm}^{-1}$. As expected, the intensity of the bands attributed to intercalated TMETA in these spectra increases with increasing salt concentration.

In Table I the main peaks of the spectra presented in Fig. 2 are summarized, as well as those of the spectra of 50poltioMMT, 100poltioMMT and 150poltioMMT, not shown. The Si-O stretching band frequency of $\mathrm{Na}^{+} \mathrm{MMT}$, at $1045 \mathrm{~cm}^{-1}$, shifts to higher wavenumbers in the organoclays, moving to $1047 \mathrm{~cm}^{-1}$ in the tioMMT clays and to $1050 \mathrm{~cm}^{-1}$ in the poltioMMT clays. This shift indicates the existence of a strong interaction of the intercalated salts with the silane groups on the surface of the lamellae [29], confirming the intercalation of TMETA and suggesting that upon polymerization a stronger interaction is established between the organic polycationic species and the clay.

As also shown in Table I the bands characteristic of TMETA are shifted to higher wave numbers in the xtioMMTs. The $\mathrm{CH}_{2}$ asymmetric and symmetric stretching bands shifted from 2926 to $2944 \mathrm{~cm}^{-1}$ and from 2860 to 2871 $\mathrm{cm}^{-1}$, respectively. These bands have been associated to the conformational order/disorder of long alkyl chains [30]. It has been shown that alkylamines confined in silicate galleries are not as ordered as in bulk crystalline solid form, but as the concentration of amines inside the galleries increases the alkyl chains tend to adopt an all-trans conformation so that the $\mathrm{CH}_{2}$ stretching bands are shifted back to a value close to that presented when in bulk crystalline amine [31].

Table I - Main FTIR peaks of TMETA, $\mathrm{Na}^{+} \mathrm{MMT}$ and the organoclays.

[Tabela I - Principais picos apresentados no FTIR no sal TMETA, $\mathrm{Na}^{+} \mathrm{MMT}$ e argilas organofilicas.]

\begin{tabular}{|c|c|c|c|c|c|c|c|c|c|}
\hline Sample & $\begin{array}{l}\mathrm{O}-\mathrm{H} \\
\left(\mathrm{cm}^{-1}\right)\end{array}$ & $\begin{array}{c}\mathrm{C} \beta-\mathrm{H} \\
\text { (arom.) } \\
\left(\mathrm{cm}^{-1}\right)\end{array}$ & $\begin{array}{l}\mathrm{C} \beta-\mathrm{H} \\
\text { (arom.) } \\
\left(\mathrm{cm}^{-1}\right)\end{array}$ & $\begin{array}{c}\mathrm{H}_{3} \mathrm{C}-\mathrm{N}^{+} \\
v_{\text {asym. }} \\
\left(\mathrm{cm}^{-1}\right)\end{array}$ & $\begin{array}{c}\mathrm{H}_{3} \mathrm{C}-\mathrm{N}^{+} \\
v_{\text {sym. }} \\
\left(\mathrm{cm}^{-1}\right)\end{array}$ & $\begin{array}{l}\mathrm{C}-\mathrm{H}_{2} \\
v_{\text {asym }} \\
\left(\mathrm{cm}^{-1}\right)\end{array}$ & $\begin{array}{c}\mathrm{C}-\mathrm{H}_{2} \\
\mathrm{v}_{\mathrm{sym}} \\
\left(\mathrm{cm}^{-1}\right)\end{array}$ & $\begin{array}{c}\mathrm{C}-\mathrm{H} \\
\delta_{\mathrm{sym}} \\
\left(\mathrm{cm}^{-1}\right)\end{array}$ & $\begin{array}{l}\text { Si-O } \\
\left(\mathrm{cm}^{-1}\right)\end{array}$ \\
\hline TMETA & - & 3070 & 3045 & 3004 & 2946 & 2926 & 2860 & 1486 & - \\
\hline $\mathrm{Na}^{+} \mathrm{MMT}$ & 3636 & - & - & - & - & - & - & - & 1045 \\
\hline 50tioMMT & 3629 & 3117 & 3044 & 3024 & 2966 & 2944 & 2871 & 1484 & 1047 \\
\hline 100tioMMT & 3631 & 3117 & 3044 & 3024 & 2966 & 2944 & 2871 & 1482 & 1047 \\
\hline 150tioMMT & 3626 & 3117 & 3044 & 3024 & 2966 & 2944 & 2871 & 1484 & 1050 \\
\hline 50poltioMMT & 3634 & - & - & - & - & - & - & 1482 & 1050 \\
\hline 100poltioMMT & 3632 & - & 3056 & 3029 & 2977 & $\begin{array}{l}2946 \\
2929\end{array}$ & $\begin{array}{l}2873 \\
2852\end{array}$ & 1482 & 1050 \\
\hline 150poltioMMT & 3628 & 3073 & 3051 & 3021 & 2977 & $\begin{array}{l}2946 \\
2929\end{array}$ & $\begin{array}{l}2874 \\
2861\end{array}$ & 1484 & 1050 \\
\hline
\end{tabular}


Therefore, we can infer from the band shifts observed that TMETA is less ordered in the silicate galleries than in bulk.

Upon polymerization of TMETA instead of one, two bands appear in the region of the $v_{\text {asym }} \mathrm{C}-\mathrm{H}_{2}$ for both 100poltioMMT and 150poltioMMT. One of the bands is shifted down to a wavenumber closer to that of the bulk crystalline TMETA and the other is shifted to a value slightly higher than that of the intercalated less organized TMETA. The same phenomenon is observed for the $v_{\text {sym }} \mathrm{C}-\mathrm{H}_{2}$ band. This indicates that the polymerized species in the poltioMMTs are present in different forms of organization giving rise to the two absorptions. Table I also shows that the band due to the $\mathrm{C} \alpha-\mathrm{H}$ stretching of the thiophene ring, which disappears upon polymerization of thiophenes [32] is still present in 100poltiofMMT and 150poltiofMMT. The change in color of the clays from beige to the reddish-browns, characteristic of conjugated polythiophenes, as well as the changes in other infrared vibrations as discussed above, lead to think that oligomeric species have been formed.

\section{$X$-ray diffraction}

Fig. 3 presents the XRD patterns for $\mathrm{Na}^{+} \mathrm{MMT}$, 50tioMMT, 100tioMMT and 150tioMMT. $\mathrm{Na}^{+} \mathrm{MMT}$ has a diffraction peak at $2 \theta=7.92^{\circ}\left(\mathrm{d}_{(001)}=1.118 \mathrm{~nm}\right)$. This peak is shifted to lower angles in the organoclays indicating expansion of the basal spacing and a successful intercalation. The basal spacing values are essentially the same for 50tioMMT, 100tioMMT and 150tioMMT, contrary to the typical increase observed when large quaternary ammonium cations, such as hexadecyltrimethylammonium bromide, are intercalated in montmorillonite clays [29, 33], but in line with the results obtained by $[34,35]$ for studies with benzyltrimethylammonium and benzyltriethylammonium, which have structures closer to that of TMETA.

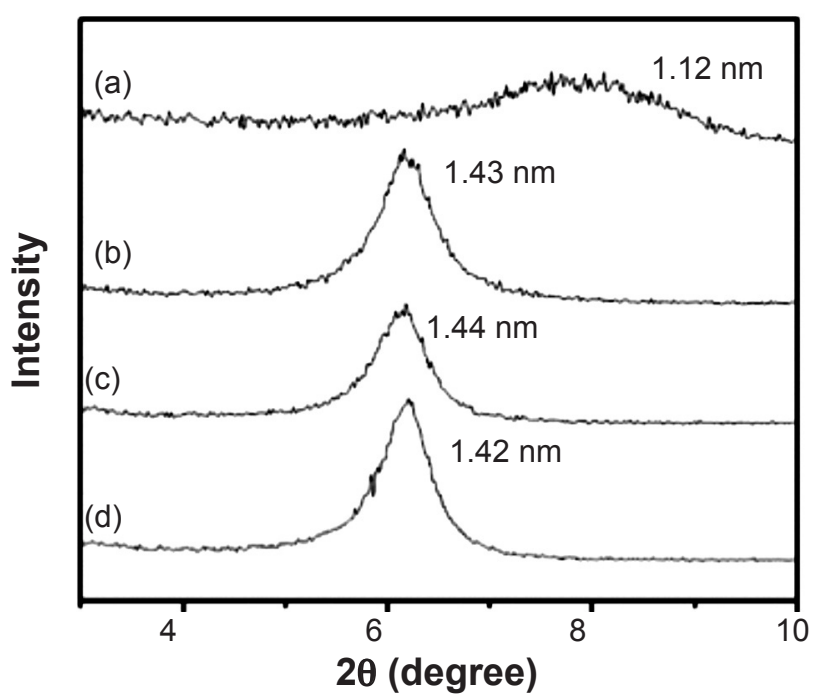

Figure 3: X-ray diffraction patterns of clays (a) $\mathrm{Na}^{+} \mathrm{MMT}$, (b) 50tioMMT, (c) 100tioMMT and (d) 150tioMMT.

[Figura 3: Difratogramas de raios $X$ das argilas (a) $\mathrm{Na}^{+} \mathrm{MMT}$, (b) 50tioMMT, (c) 100tioMMT e (d) 150tioMMT.]

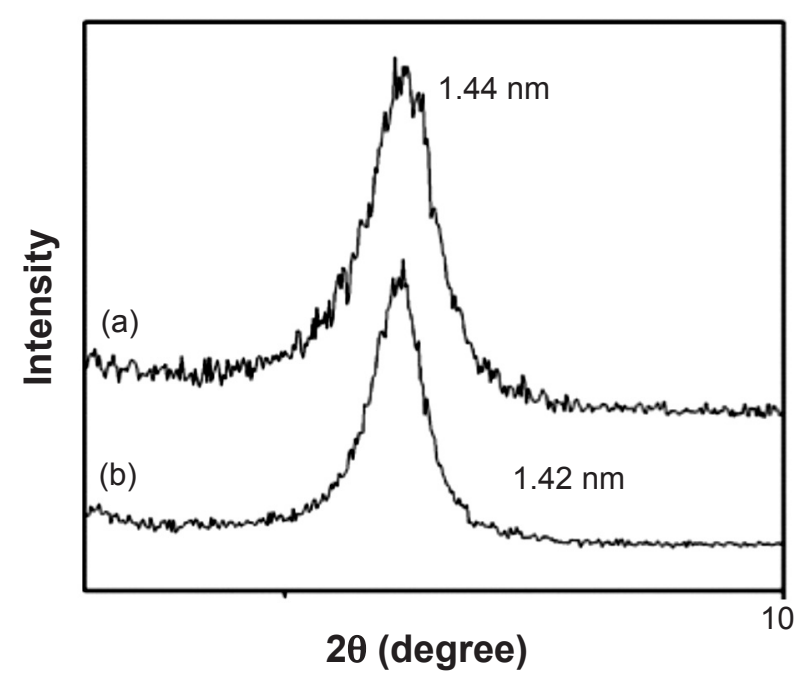

Figure 4: X-ray diffraction patterns of montmorillonites (a) 100tioMMT and (b) 100poltioMMT.

[Figura 4: Difratogramas de raios $X$ das montmorilonitas (a) 100tioMMT e (b) 100poltioMMT.]

XRD pattern of the clays intercalated with the polymerized TMETA shows a small decrease in the interlayer spacing when compared to the tioMMTs organoclays, particularly for the organoclays 50tioMMT and 100tioMMT, as illustrated in Fig. 4 which presents the XRD patterns for 100tioMMT e 100poltioMMT. Similarly, a decrease in the basal spacing of montmorillonite intercalated with aniliniun ions upon polymerization to polyaniline was observed in [7], which showed that the intercalated polymeric chains lied flat between the layers. A decrease in the half width of the peak is also observed in Fig. 4 indicating an increase in homogeneity of the sample with polymerization $[36,37]$.

\section{Thermal analysis}

The thermogravimetric analyses for $\mathrm{Na}^{+} \mathrm{MMT}$ and the organoclays are shown in Fig. 5 and the thermogravimetric events are summarized in Table II. The first event between 40 and $100^{\circ} \mathrm{C}$ is common to all MMTs and is due to the loss of free water and of water inside the clay's lamellae. These losses were $7.94 \%$ for $\mathrm{Na}^{+} \mathrm{MMT}, 3.21 \%$ for both 50tioMMT and 100tioMMT, and $1.98 \%$ for 150 tioMMT showing that the hydrophilic character of the clay has been considerably lowered upon intercalation. A decrease in the quantity of water lost with an increase in the amount of alkylic salts intercalated has been reported in the literature, and it has also been observed that for intercalation above the CEC water loss remains constant [38]. In this study a decrease in water loss is observed for 150tioMMT in relation to 50tioMMT and 100tioMMT which indicates that the $\mathrm{Na}^{+}$ cations have not been completely exchanged in these clays. A second event of thermal degradation, between 200 and $500{ }^{\circ} \mathrm{C}$, is observed for the organoclays exclusively and characterizes the decomposition of TMETA. The onset of decomposition occurs at $315.1{ }^{\circ} \mathrm{C}$ for 50tioMMTand at $408.1{ }^{\circ} \mathrm{C}$ for 100 tioMMT. The increase in the temperature 

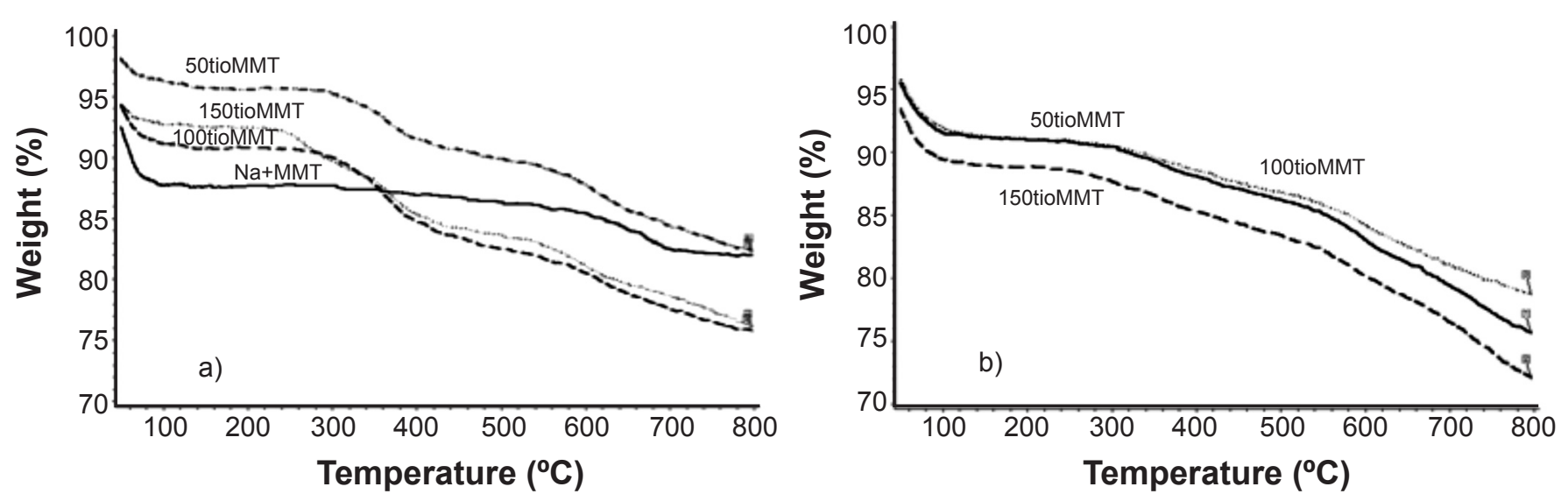

Figure 5: TG analysis curves of (a) $\mathrm{Na}^{+} \mathrm{MMT}$, 50tioMMT, 100tioMMT, 150tioMMT and (b) 50poltioMMT, 100poltioMMT, 150poltioMMT.

[Figura 5: Curvas de análise TG de (a) Na+MMT, 50tioMMT, 100tioMMT, 150tioMMT e (b) 50poltioMMT, 100poltioMMT, 150poltioMMT.]

Table II - Thermal events and weight loss for $\mathrm{Na}^{+} \mathrm{MMT}$ and organoMMT.

[Tabela II - Eventos térmicos e percentuais de perda de massa das argilas $\mathrm{Na}^{+} \mathrm{MMT}$ e organoMMT.]

\begin{tabular}{cccccccc}
\hline & \multicolumn{3}{c}{ Dehydratation } & \multicolumn{5}{c}{ TMETA Decomposition } & Dehydroxylation \\
& $\begin{array}{c}\mathrm{T}_{\text {onset }} \\
\left({ }^{\circ} \mathrm{C}\right)\end{array}$ & $\begin{array}{c}\text { Water } \\
\text { content } \\
(\mathrm{wt} \%)\end{array}$ & $\begin{array}{c}\mathrm{T}_{\text {onset }}\left({ }^{\circ} \mathrm{C}\right) \\
\text { Organic } \\
\text { content } \\
(\mathrm{wt} \%)\end{array}$ & $\begin{array}{c}\mathrm{T}_{\text {onset }} \\
\left({ }^{\circ} \mathrm{C}\right)\end{array}$ & $\begin{array}{c}\text { Organic } \\
\text { content } \\
(\mathrm{wt} \%)\end{array}$ & $\mathrm{T}_{\text {onset }}\left({ }^{\circ} \mathrm{C}\right)$ \\
\hline Na ${ }^{+} \mathrm{MMT}$ & 66.9 & 7.94 & - & - & - & - & 583.0 \\
50tioMMT & 61.3 & 3.21 & - & - & 315.1 & 5.86 & 537.3 \\
100tioMMT & 68.9 & 3.21 & - & - & 408.1 & 7.88 & 750.5 \\
150tioMMT & 74.0 & 1.98 & 202.8 & 4.07 & 403.2 & 4.96 & 591.5 \\
50 poltio MMT & 78.9 & 4.95 & - & - & 292.4 & 4.36 & 543.7 \\
100poltioMMT & 83.4 & 4.76 & - & - & 325.8 & 5.41 & 637.2 \\
150poltioMMT & 81.6 & 4.88 & 230.1 & 2.14 & 351.1 & 3.45 & 449.5 \\
\hline
\end{tabular}

of degradation for 100tioMMT might be attributed rather to the slower diffusion rate of the salt in the more crowed interlayer spacing than to a greater stability of the salt in 100tioMMT when compared to that in 50tioMMT $[39,40]$. For 150tioMMT two events due to TMETA degradation are observed. The first at $202.8^{\circ} \mathrm{C}$ is due to the decomposition of excess salt adsorbed, on the clay's surfaces or inside the lamellae [41], and the second at $403.2{ }^{\circ} \mathrm{C}$ happens due to degradation of the ionically linked salt exchanged for the $\mathrm{Na}^{+}$cations. An extensive study by [38], using ten different compositions of hexadecylammoniun and a sodium montimorillonite, showed a clear decrease in the temperature of degradation with an increase in salt content.

As expected the weight percent of decomposed salt increases with increasing intercalation being 5.86\%, 7.88\% and $9.03 \%$ for 50tioMMT, 100tioMMT and 150tioMMT, respectively. As discussed below these values indicate that only part of the salt loaded in the preparation mixture was adsorbed in the clay. An estimative of the values actually incorporated are shown in Table III. Incorporated values were estimated from the thermogravimetric data and should rest between a maximum and a minimum value obtained according to equation:

$$
\mathrm{X}=\frac{\mathrm{S} \% \times 10^{5}}{76,4(\mathrm{M}-\mathrm{y}) \times(100-\mathrm{S} \%)}
$$

where $\mathrm{X}$ is the loaded surfactant, $\mathrm{S} \%$ is the $\%$ of weight loss of thiophene salt in the organoclay, $\mathrm{M}$ is the molecular weight of the thiophene salt; $\mathrm{y}$ is 0 if all $\mathrm{Br}^{-}$remains and 80 if no $\mathrm{Br}^{-}$remains [29]. The maximum value is calculated assuming that no bromide anion was incorporated while the minimum is obtained assuming the incorporation of 
Table III - TMETA adsorbed in the organoclays (calculated from TG data) [29]. [Tabela III - Percentuais de TMETA adsorvido nas argilas organofilicas (calculados através dos resultados de TG) [29].]

\begin{tabular}{cccc}
\hline Sample & \multicolumn{2}{c}{ TMETA adsorbed in the } & organoclays relative to CEC \\
& Min $(\%)$ & Max $(\%)$ & $\begin{array}{c}\text { BTMTA Loaded in } \\
\text { the preparation } \\
\text { relative to CEC }(\%)\end{array}$ \\
\hline 50tioMMT & 32.6 & 47.9 & 50 \\
100tioMMT & 44.8 & 65.9 & 100 \\
150tioMMT & 52.0 & 76.4 & 150 \\
50poltioMMT & 23.9 & 35.7 & - \\
100poltioMMT & 29.9 & 44.0 & - \\
150poltioMMT & 31.0 & 45.6 & - \\
\hline
\end{tabular}

both the ammonium cation and its bromide counter ion. For 50tioMMT the incorporated value is very close to the loaded value if no bromine has been incorporated, but as the amount of salt added increases, the relative amount of incorporated salt clearly decreases as seen for 100tioMMT and 150tioMMT. This is in accordance with literature results which points to the difficulty of incorporation of small quaternary ammonium cations $[34,35]$.

Between 500 and $800{ }^{\circ} \mathrm{C}$ an event characterizing dehydroxilation of the clay is observed in Table II. For $\mathrm{Na}^{+} \mathrm{MMT}$ it starts at $583{ }^{\circ} \mathrm{C}$ and for 50tioMMT at $537.1{ }^{\circ} \mathrm{C}$. For 100tioMMT and 150tioMMT dehydroxilation starts at 750.5 and $591.5{ }^{\circ} \mathrm{C}$, respectively. The thermogravimetric events for the organoMMTs after in situ polymerization of the intercalated salt are the same as those of the parent organoclays (Table II). An increase in dehydration temperature and in the water lost relative to the respective parent organoclay is observed indicating a decrease in hydrophobicity after polymerization of the salt. A decrease in the onset of degradation of the polymeric salt and in the weight loss is also observed. The decrease in weight loss might be due to the degradation of part of the salt during polymerization and the washing off of the degradation products during work up. The polymerization of thiophenes by oxidative coupling with ferric chloride leaves $\mathrm{HCl}$ as a by-product [42] and the presence of residual halide ions has been shown to cause the decomposition of surfactant salts inside the clay lamellae [41].

\section{CONCLUSIONS}

TMETA can be exchanged for the sodium cations in $\mathrm{Na}^{+} \mathrm{MMT}$, as indicated by the expansion of the basal spacing, shown by X-ray diffraction, and by the presence of bands characteristic of TMETA in the FTIR spectra of the modified clays. FTIR also indicates that the salt intercalated in the silicate galleries is less organized than in the bulk solid state. The amount of TMETA intercalated is lower than the salt loaded in the preparation mixture, and as the amount of salt loaded is increased intercalation increases but not proportionally, as calculated from thermal analysis data.
TMETA can be polymerized inside the lamellae giving rise to oligomeric conjugated species which interact more strongly with the clay than the mono-cations, as inferred from their FTIR spectra. Polymerization also leads to a decrease in basal spacing along with an increase in the homogeneity of the basal spacing sizes in the sample, and to a decrease in the thermal stability of the organoclay.

\section{ACKNOWLEDGEMENTS}

We are thankful to FACEPE, CNPq and CAPES for financial support, to Southern Clay products for donating the montmorillonite clay used in this work and to CETENE (Centro de Tecnologias Estratégicas do Nordeste) for the use of their analytical facilities.

\section{REFERENCES}

[1] S.S. Ray, M. Okamoto, Prog. Polym. Sci. 28 (2003) 1539-1641.

[2] P. Liu, Appl. Clay Sci. 38, 1-2 (2007) 64-76.

[3] J. Zhang, E. Manias, C. Wilkie, J. Nanosci. Nanotechn. 8, 4 (2008) 1597-1615.

[4] Z.M. Wang, H. Nakajima, E. Manias, T.C. Chung, Macromolecules 36, 24 (2003) 8919-8922.

[5] J. Zhang, D.D. Jiang, C. Wilkie, Thermochim. Acta 430, 1-2 (2005) 107-113.

[6] K.R.L. Castagno,V. Dalmoro, R.S. Mauler, D.S. Azambuja, J. Polym. Res. 17, 5 (2009) 647-655.

[7] G.M. Nascimento, M.L. Temperini, J. Mol. Struc. 1002, 1-3 (2011) 63-69.

[8] R.M.G. Rajapakse, S. Higgins, K. Velauthamurty, H.M.N. Bandara, S. Wijeratne, R.M.M.Y. Rajapakse, J. Compos. Mater. 45, 5 (2010) 597-608.

[9] L.C.T. Shoute, Y. Wu, R.L. McCreery, Electrochim. Acta, 110 (2012) 437-445.

[10] R.S. Sulub, W. Martínez-Millán, M.A. Smit, Int. J. Electrochem. Sci 4 (2009) 1015-1027.

[11] X. Ma, G. Li, H. Xu, M. Wang, H. Chen, Thin Solid Films 515, 4 (2006) 2700-2704.

[12] A. Uygun, A.G. Yavuz, S. Sen, M. Omastová, Synth. 
Metals 159, 19-20 (2009) 2022-2028.

[13] B.K. Kuila, A.K. Nandi, Macromolecules 37 (2004) 8577-8584.

[14] B.K. Kuila, A.K. Nandi, J. Phys. Chem. B 110, 4 (2006) 1621-31.

[15] B.K. Kuila, A.K. Nandi, J. Appl. Polym. Sci. 111 (2008) 155-167.

[16] Y. Yu, C. Jen, H. Huang, P. Wu, C. Huang, J. Yeh, J. Appl. Polym. Sci. 91 (2004) 3438-3446.

[17] J.C. Macêdo-Fonsêca, I.S. Silva, R.M. Souto-Maior, Synth. Met. 159, 21-22 (2009) 2215-2218.

[18] M. Era, S. Yoneda, T. Sano, M. Noto, Thin Solid Films 438-439 (2003) 322-325.

[19] Z. Yang, X. Kou, W. Ni, Z. Sun, L. Li, J. Wang, Chem. Mater. 19, 25 (2007) 6222-6229.

[20] G. Li, S. Bhosale, T. Wang, Y. Zhang, H. Zhu, J.H. Fuhrhop, Angew. Chem. Int. Ed. 42, 32 (2003) 3818-3821.

[21] K.K. Stoke, K. Heuze, R.D. Mccullough, Macromolecules 36 (2003) 7114-7118.

[22] S.M.L. Silva, P.E.R. Araujo, K.M. Ferreira, E.L. Canedo, L.H. Carvalho, C.M.O. Raposo, Polym. Eng. Sci. 49, 9 (2009) 1696-1702.

[23] J.E. Osterholm, P. Sunila, Synth. Met. 18 (1987) 169176.

[24] L'. Jankovič, J. Madejová, P. Komadel, D. JochecMošková, I. Chodák, Appl. Clay Sci. 51, 4 (2011) 438-444. [25] G. Louarn, J.P. Buisson, S. Lefrant, L.D.P. Cristalline, Synth. Met. 57 (1993) 587-592.

[26] M. Kozak, L. Domka, J. Phys. Chem. Solids 65, 2-3 (2004) 441-445.

[27] F.A. Miller, C.H. Wilkins, Anal. Chem. 24 (1952)
1253-1294.

[28] J. Madejova, Vib. Spectrosc. 31 (2003) 1-10.

[29] Y. Xi, R.L. Frost, H. He, J. Colloid Interface Sci. 305, 1 (2007) 150-158.

[30] R.A. Vaia, R.K. Teukolsky, E.P. Giannelis, Chem. Mater. 6, 16 (1994) 1017-1022.

[31] Y. Li, H. Ishida, Langmuir : the ACS J. Surf. Colloids 48, 12 (2003) 2479-2484.

[32] R.M. Souto Maior, H. Eckert, Macromolecules 1279, 10 (1990) 1268-1279.

[33] H. He, Y. Ma, J. Zhu, P. Yuan, Y. Qing, Appl. Clay Sci. 48, 1-2 (2010) 67-72.

[34] T. Polubesova, G. Rytwo, S. Nir, C. Serban, L. Marguliest, M. Galilee, K. Shmona, Clay Clay Miner. 45, 6 (1997) 834-841.

[35] S.-M .Koh, J.B. Dixon, Appl. Clay Sci. 18, 3-4 (2001) 111-122.

[36] M.A. Osman, E.P. Rupp, U.W. Suter, Polymer 46 (2005) 8202-8209.

[37] K. Yoon, H. Sung, Y. Hwang, S. Kyun Noh, D. Lee, Appl. Clay Sci. 38, 1-2 (2007) 1-8.

[38] S.I. Marras, A. Tsimpliaraki, I. Zuburtikudis, C. Panayiotou, J. Colloid Interface Sci. 315, 2 (2007) 520-527. [39] H. He, Z. Ding, J. Zhu, P. Yuan, Y. Xi, D. Yang, R.L. Frost, Clay Clay Miner. 53, 3 (2005) 287-293.

[40] W. Xie, Z. Gao, W.P. Pan, D. Hunter, A. Singh, R. Vaia, Chem. Mater. 13, 9 (2001) 2979-2990.

[41] L. Cui, D.M. Khramov, C.W. Bielawski, D.L. Hunter, P.J. Yoon, D.R. Paul, Polymer 49, 17 (2008) 3751-3761.

[42] V.M. Niemi, P. Knuuttila, N. Oy, J. Korvola, Polymer 33, 7 (1992) 1559-1562.

(Rec. 18/08/2015, Rev. 08/11/2015, Ac. 15/12/2015) 